\title{
Overview of Organic Cover Crop-Based No-Tillage Technique in Europe: Farmers' Practices and Research Challenges
}

\author{
Laura Vincent-Caboud ${ }^{1, *}$, Joséphine Peigné ${ }^{1}$, Marion Casagrande ${ }^{1,2}$ and Erin M. Silva ${ }^{3}$ \\ 1 Department of Agroecology and Environment, ISARA-Lyon (member of the University of Lyon), 23 rue Jean \\ Baldassini, F-69364 Lyon Cedex 07, France; jpeigne@isara.fr (J.P.); marion.casagrande@itab.asso.fr (M.C.) \\ 2 ITAB, Quartier Marcellas, F-26800 Etoile sur Rhône, France \\ 3 Department of Agronomy, University of Wisconsin-Madison, Madison, 53706 WI, USA; emsilva@wisc.edu \\ * Correspondence: lavincent-caboud@isara.fr; Tel.: +33-042-785-8573
}

Academic Editors: Patrick Carr and Les Copeland

Received: 8 February 2017; Accepted: 28 April 2017; Published: 4 May 2017

\begin{abstract}
Cover crop mulch-based no-tillage (MBNT) production is emerging as an innovative alternative production practice in organic farming (OF) to reduce intensive soil tillage. Although European organic farmers are motivated to implement MBNT to improve soil fertility and achieve further management benefits (e.g., labor and costs savings), low MBNT practice is reported in Europe. Thus, this paper aims to understand the challenges of both farmers and researchers limiting the further adoption of MBNT in organic farming in temperate climates. The primary no-tillage (NT) practices of organic European farmers and findings of organic MBNT studies conducted in Europe are reviewed, focusing on living or mulch cover crop-based NT (LBNT or MBNT) for arable crop production. Major conclusions drawn from this review indicate consistent weed control and an establishment of best practices for cover crop management as the two main overarching challenges limiting adoption. In view of substantial gaps of knowledge on these issues, additional research should focus on cover crop selection and management (species, date of sowing) to increase cover crop biomass, particularly in warmer climates. Lastly, further research is needed to optimize cover crop termination to prevent competition for water and nutrients with cash crops, particularly in wetter northern conditions which promote vigorous cover crop growth.
\end{abstract}

Keywords: no tillage; cover crops; organic farming; roller crimper; conservation tillage

\section{Introduction}

Conservation agriculture (CA) has been developed in conventional farming to minimize and prevent soil erosion, reduce labor and energy inputs, and preserve soil fertility [1-4]. The Food and Agriculture Organization (FAO) has defined conservation agriculture as a range of practices based on three main principles: (1) minimum soil disturbance obtained using reduced-tillage (RT) or no-tillage (NT); (2) a permanent soil cover via living or dead (mulch) cover crops; and (3) diversified crop rotations [2]. NT involves production practices with which a cash crop is sown into soil that has not been tilled since the previous harvest [5] (Figure 1). As highlighted by several authors, NT may also be referred to as direct seeding or direct drilling, terms that are often employed in European publications [3,6], although some North American researchers have stressed differences in soil disturbance between NT and direct drilling [7]. Typically, with the use of NT practices, the soil surface is only disturbed down to three to five centimeters in depth in the seeding row, with significant amounts of crops or cover crop residues is maintained on the soil surface to preserve soil quality and suppress weeds [8]. 


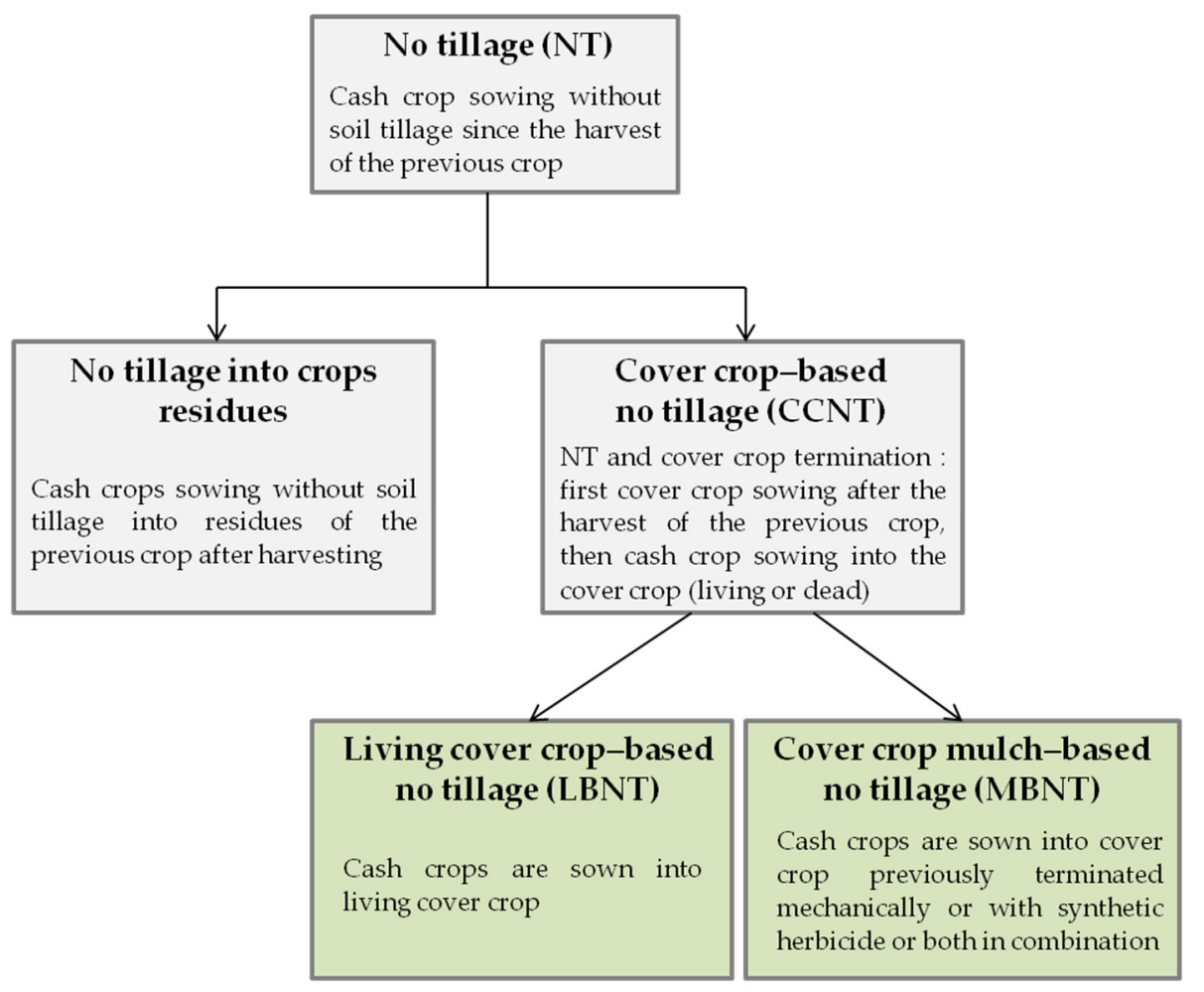

Figure 1. Diagram of different techniques of no-tillage and cover crop management.

The specific integration of cover crops into NT practices is an innovative alternative recently developed to mitigate environmental pollution, such as nitrate leaching, reduce inputs (fertilization, herbicides), and suppress weeds via cover crop competition for nutrient and water resources $[9,10]$ (Figure 1). Cover crop mulch-based NT and living cover crop-based NT have gained increasing attention as methods to further enhance the agroecosystem services of NT systems, particularly in organic agriculture. Depending on the cover crop species used in the system, weed control is achieved through physical suppression preventing access to light, and reducing soil temperatures, competition with nutrient resources, and allelopathic interactions [11]. Cover crop-based NT (CCNT) techniques, i.e., MBNT and LBNT, consist of sowing the main crop into a living cover crop, frost-killed cover crop, or cover crop terminated either mechanically (roller crimper, mower) or with a synthetic herbicide, or both in combination (Figure 1). These strategies, in addition to limiting soil disturbance and suppressing weeds, also provides an opportunity to address another principle of conservation agriculture by improving living soil cover. Although CCNT is employed in conventional agriculture to promote soil fertility, control weeds, increase water infiltration, and preserve soil moisture [12], these systems often integrate the use of herbicides to manage weeds and/or terminate the cover crop, thereby raising environmental sustainability issues [8,13].

Organic farming (OF) has also emerged as an alternative for maintaining soil fertility and reducing the harmful environmental impacts of agriculture. The European standard No. 834/2007 bans the use of chemical synthetics (pesticides and fertilizers) and limits off-farm and synthetic inputs in OF. Current organic practices use crop rotation as a foundational practice to provide nutrient recycling and to control weeds, pests, and diseases [14]. Theoretically, OF offers many advantages in the shift toward sustainable agricultural systems via the increase of soil organic matter and biodiversity. In reality, however, without use of synthetic herbicides, farmers often depend on intensive tillage to manage weeds $[15,16]$. This can result in soil degradation: decreases in biological activity and biodiversity, increases in soil erosion, losses in organic matter content, and destruction of soil physical structure due to frequent machine traffic and tillage activities on the field $[17,18]$. Organic NT 
represents an opportunity to mitigate these drawbacks, improve soil fertility components, and provide further benefits regarding European farmers' working conditions (labor savings, energy consumption reduction, etc.) [13].

Despite the potential benefits of integrating NT practices into organic cropping systems (including, but not limited to, MBNT and LBNT) which have been reported by researchers, and the interest shown by European farmers, NT has not been widely implemented in Europe and few research studies have been conducted investigating this technique $[19,20]$. The trials that have been carried out in Europe and interviews with farmers using organic conservation tillage including MBNT bring to light the typical practices, motivations, and challenges related to conservation techniques $[19,20]$. This paper aims to synthesize knowledge and conclusions drawn from previous European research projects to identify the overarching challenges facing research in Europe in the promotion of organic MBNT in arable crops.

Based on a literature review and interviews of European organic farmers, we first explain the methodology selected to address the goal of this paper. Then, we present a broad overview of organic farmers' NT and cover crop practices in Europe and identify their main challenges. Next, we examine, in detail, the knowledge drawn from European research to address the organic farmers' difficulties. Lastly, we discuss the primary future research challenges to improve our understanding of organic MBNT under a temperate climate.

\section{Methodology}

Several papers have been published in North America on organic MBNT, summarizing the results of research trials based on cover crop species [21-26], cover crop termination methods and timing [24,27-33], weed suppression [34-41], and cash crop sowing (fertilization strategies, row spacing, seeding rate) $[24,42,43]$. Nevertheless, in Europe, very few studies exist that focus on organic MBNT, raising questions of the effectiveness and appropriateness of this technique to enhance the sustainability of European organic farms [44]. Concerns related to the implementation of organic MBNT in Europe must be articulated to identify future research specifically addressing the implementation of MBNT on European farms. Indeed, despite the robust discussion of the challenges related to MBNT by American researchers [16,35,36,39], these challenges may differ in Europe due to its unique agricultural context (e.g., climate, information or equipment access, organic seed availability, etc.).

In Europe, although a range of studies and review articles have been carried out on NT in conventional farming $[8,45,46]$, these papers did not specifically address MBNT, leaving a dearth of information on MBNT, particularly regarding its unique integration into organic production. In Europe, published papers dealing with tillage issues in OF are focused on RT, and it is difficult to discern from this knowledge about NT [13,15,17,20,44,47-49]. While there are some references referring to organic MBNT in arable crops, data analysis on this technique is often presented in the context of a comparison with traditional ploughing and RT $[15,20,50-52]$. This research strategy limits the generation of data which could contribute to the refinement of the MBNT technique and the development of best management practices, while diluting access of MBNT information.

In order to address this resource gap, this review paper focuses solely on organic MBNT and LBNT, identifying challenges specific to these NT techniques on organic European farms. The review is organized into four sections: the first two sections summarize MBNT and LBNT practices and challenges on European organic farms, considering separately two distinct climatic regions in Europe: the northern region $\left(>45^{\circ} \mathrm{N}\right)$ and the southern region $\left(\leq 45^{\circ} \mathrm{N}\right)$. These sections are informed by two surveys, one conducted across Europe and the second focused on France, which aimed to identify conservation practices of organic farmers focusing on NT, RT, and green manure techniques $[19,20,53]$. Green manure, also called cover crop, is referred to as any crops implemented with the aim of soil fertility preservation and improvement. While certain aspects of these surveys' data have been published elsewhere, we will employ a unique approach focusing solely on the farmer-reported practices and perceptions regarding NT and cover crop management, and place the survey information 
against the backdrop of the European literature on conservation agricultural practices in both organic and conventional systems, creating a framework upon which to overview knowledge and challenges specific to the organic MBNT in Europe $[13,17,18,54,55]$. In particular, review papers focused on the implementation of NT practices within the European biological, physical, and chemical contexts are used to describe the pedo-climatic effects on MBNT implementation in Europe [3,8,46,56]. In the third section, we summarize research focused on organic CCNT (i.e., MBNT and LBNT) in Europe, which further informs the fourth section, in order to identifying remaining gaps in the understanding of MBNT in Europe needed to promote farmer adoption and success with techniques combining NT with intensive cover cropping.

\section{European Organic Farmers' No-Tillage and Cover Crop Practices}

Existing published literature describing the results of controlled NT research studies, do not necessarily report on the specific attitudes and practices employed by European farmers' using MBNT or LBNT practices. Within the literature that does describe farmer implementation of MBNT practices, farmers report low adoption of organic MBNT and LBNT techniques, in part due to challenges with consistent termination of cover crops without the use of synthetic herbicides [13,47]. A recent European survey carried out in 2012 with 159 organic farmers who are applying conservation principles (i.e., at least one of the following practices: reduced tillage, cover crop, no tillage) (see [20]) revealed that even within this progressive cohort of farmers utilizing sustainable RT and cover crop practices, only $27 \%$ of interviewed farmers used NT techniques [20]. This mirrored the results of an earlier 2010 French survey interviewing 24 producers, which also confirmed that very few farmers had experimented MBNT [53].

\subsection{Organic No-Tillage and Cover Crop Practices in Europe}

Organic NT approaches vary across Europe, largely due to differences in climate, national cultures, and/or information access [20]. Much of Europe experiences a temperate climate, with consistent humid and cool conditions, as compared to other regions of the globe with higher seasonal rainfall and/or drought periods, as encountered in North America [8]. However, warmer and drier climates can be found in Southern Europe, with these types of environments expected to expand with global warming, increasing the risk of soil degradation [8]. With these changes in climatic conditions, interest in organic NT is expected to increase as additional production strategies are sought to reduce soil erosion and preserve soil moisture in the face of increasing extreme weather events. In this section, we will discuss the main practices and challenges in two European areas: the northern region $\left(>45^{\circ} \mathrm{N}\right)$, where 109 organic farmers were interviewed in 2012 , and the southern region $\left(\leq 45^{\circ} \mathrm{N}\right.$, with 50 interviewed farmers interviewed in 2012). Conservation practices implemented by these farmers may cover a range of techniques [20], but we focus in this paper on NT (including MBNT and LBNT), in tandem with the cover crop information drawn from these surveys.

As reported in the 2012 aforementioned survey of organic farmers using progressive, sustainable practices, in the northern part of Europe, only $23 \%$ of the 109 interviewed farmers used NT, while $93 \%$ of farmers implemented a cover crop in their crop rotation to increase soil $\mathrm{N}$ supply to the subsequent crop [20]. Maëder and Berner [13] have shown that the humid and cool conditions experienced in northern climates increases the difficulty of implementing NT. Researchers have recognized the role of tillage in managing weeds and accelerating soil warming to foster crop emergence, which otherwise could be delayed by large quantities of mulch left on the soil surface (Table 1). Furthermore, humid conditions enable cover crops to be established rapidly, thus influencing northern farmers' focus on cover crop practices rather than NT [20].

Conversely, in the southern part of Europe, $34 \%$ of the 50 interviewed farmers use NT, with only $48 \%$ implementing a cover crop [20]. NT is more widespread among southern farmers, likely due to soil degradation and soil water loss caused by intensive tillage under warm and dry conditions where soil is more exposed to water and wind erosion [8]. Moreover, higher temperatures accelerate soil 
warming, promoting crop emergence and contributing to the success of NT (Table 1). However, while implementation NT practices were greater among the southern farmers, this group demonstrated a decreased use of cover crops as compared with northern European farmers. This illustrates the trade-offs regarding sustainable practices which exist in the south; while cover crops are difficult to establish in the water-limited southern climate, this same condition promotes alternative sustainable practices, the adoption of intensive non-inversion tillage strategies to manage weeds, maintain yields, and incorporate fertilizers to limit ammoniac volatilization [20]. Due to these trade-offs, the implementation of multiple practices integrating NT principles, i.e., including LBNT and MBNT, represents a real challenge.

\subsection{Cover Crop Management}

The majority of the 159 interviewed farmers implemented cover crops in their crop rotation strategies, but only $19 \%$ of them combined NT with a cover crop [20], likely due to the limited termination methods for cover crops in $\mathrm{OF}$, which relies exclusively either on a mechanical solution or frost [18]. Cover crop regrowth due to inconsistent or incomplete termination may compete with the cash crop for nutrients and water resources. Detailed management descriptions of the winter cropping practices of 68 farmers applying cover crops showed that most terminated the cover crop by undercutting or mowing, but only $2 \%$ of them by rolling [20]. Thus, the cover crop often remained a living cover when combined with MBNT. Moreover, organic farmers recognized the critical trade-offs between the management of the cover and cash crops, including the impacts on (i) managing weeds with the use of a false seed-bed or (ii) incorporating a cover crop to provide nitrogen $(\mathrm{N})$ to the subsequent crops [57]. Such practices do not appear to be aligning cover crop management with MBNT principles. Thus, alternatives are needed to help organic farmers manage weeds and allow for the incorporation of $\mathrm{N}$-rich cover crops without tilling.

\subsection{Application in Crop Rotations}

NT primarily integrates the use of winter cereal crops, such as wheat (Triticum vulgare L.), barley (Hordeum vulgare L.), or triticale ( $x$ Triticosecale spp. L.), seeded into a living cover crop or by direct sowing following the harvest of the previous main crop. Only $2.5 \%$ of the 40 interviewed farmers using NT in Europe sowed spring crops (e.g., soybean (Glycine max L.) or corn (Zea mays L.)) using NT practices [20], with the practice only implemented where conditions are ideal (e.g., low weed pressure, good climate conditions, etc.).

The length of crop rotations in which NT crops are included averaged seven years [20]. Diversified crop rotations are typically used, including cereals, legumes, and other species, such as Brassicacae. Among the 40 farmers using NT, crop rotations are mainly based on alternating spring and winter crops to manage weeds, and include an average of $25 \%$ spring crops, $35 \%$ winter crops, $10 \%$ other legume crops, and 30\% cover crops used to increase soil $\mathrm{N}$ supply to the subsequent crop. Tillage is generally not completely absent from crop rotations, and occasional ploughing is performed at some stages (e.g., before spring sowing, or to incorporate cover crops). Farmers limit the application of NT on specific crops in crop rotation (e.g., wheat, barley, etc.) with occasional ploughing at a mean frequency of 0.6 times over 10 years among the interviewed farmers [20].

\subsection{Farmers' Experience in No Tillage Production}

The European survey showed that organic farmers lack experience in NT, with only five years of practice compared with an average of 16 years with the use of cover crops [20]. Results indicated that only $10 \%$ of 40 organic farmers using NT applied this technique without adopting RT practices, with farmers using NT averaging 12 years of experience in RT and 13 years in cover crops. This latter finding suggests that farmers using NT are not the most experienced in CA, confirming what has also been observed in the French survey [53]. Organic farmers' progress in NT techniques occurs through 
exploring solutions on a farm-by-farm basis, integrating the unique objectives and constraints of their farm organization.

The situation across Northern Europe contrasts with southern farmers who have slightly greater experience in NT, with an average of seven years of practice, as opposed to five years in northern areas among the 40 interviewed farmers applying NT [20]. These differences in farmers' practices and experiences using NT highlight the need for better understanding of the main challenges unique to their regions and farming systems if relevant solutions are to be provided in a broader European context.

This overview of NT and cover crop practices in Europe reveals the obstacles facing organic farmers to combine both techniques in accordance with the pedo-climatic context (Table 1).

Table 1. Opportunities and challenges for organic MBNT adoption in the European context.

\begin{tabular}{lll}
\hline \multicolumn{1}{c}{ European Regions } & \multicolumn{1}{c}{ Opportunities } & \multicolumn{1}{c}{ Challenges } \\
\hline Northern areas $\left(>45^{\circ} \mathrm{N}\right)$ & $\begin{array}{l}\text { High cover crop biomass potential } \\
\text { Large number of farmers with } \\
\text { experience of cover crop practices } \\
\text { Soil preservation to cope with } \\
\text { climate change }\end{array}$ & $\begin{array}{l}\text { Slow soil warming } \\
\text { Moisture conditions foster rapid weed } \\
\text { development and degradation of cover } \\
\text { crop residues } \\
\text { Cover crop management/termination difficulties } \\
\text { Low NT adoption }\end{array}$ \\
\hline Fouthern areas $\left(\leq 45^{\circ} \mathrm{N}\right)$ & $\begin{array}{l}\text { Fast soil warming reduces soil } \\
\text { erosion and maintains soil moisture } \\
\text { in the face of climate change } \\
\text { More experienced farmers in NT }\end{array}$ & $\begin{array}{l}\text { Water and nutrient deficiencies for the cash crop } \\
\text { (more irrigation required) } \\
\text { Less application of cover crops in the crop rotation } \\
\text { Cover crop establishment difficulties (under warm } \\
\text { and dry conditions) }\end{array}$ \\
& Fewer farmers experienced in cover crop practices
\end{tabular}

$\mathrm{NT}=$ no-tillage $; \mathrm{CA}=$ conservation agriculture .

\section{The Challenges of Living or Killed (Mulch) Cover Crop-Based No-Tillage in European Organic Farming}

\subsection{Weed Management}

European researchers indicated insufficient weed suppression and resulting high weed pressures as the main reason for the low adoption of organic NT practices in Europe [48,49,58,59]. For some farmers, CCNT practices (MBNT and LBNT) offer a means of suppressing weeds without mechanical methods; however, maintaining weed suppression throughout the entire cash crop production season from crop sowing through to harvest was cited as a major difficulty raised by farmers (Figure 2) [19]. Lefèvre et al. [53] also stressed weed suppression as a primary concern of interviewed French farmers. Indeed, the possible need to intensify mechanical weed control during a crop rotation including NT due to inadequate weed management in the NT phase may lead to additional issues at the rotational scale (e.g., soil erosion, increase in labor and investment, etc.). This problem is illustrated by current farmer practices where tillage is not entirely removed from the crop rotation [20]; weed management concerns appear more important for northern farmers who are slower to adopt NT practices (Figure 2). In northern environments, humid conditions promote weed development throughout the cash crop production season, including in CCNT if the residue biomass is inadequate to provide season-long weed suppression; with significant cover crop residue on the soil surface, CCNT limits the ability of farmers to employ mechanical methods of weed management.

\subsection{Inadequacy of Available NT Equipment and Low Technical Skills and Information}

European farmers reported an inability to access information related to the organic NT technique to guide their management decision [19]. More specifically, Peigné et al. [20] found that southern farmers have less access to NT information resources than northern farmers, despite the higher number of NT practitioners observed in South Europe. According to Lefèvre et al. [53], the shortage of technical guidelines leads farmers to explore solutions independently on their own farms. For example, lack of 
knowledge as to the best practices for seeding cash crops into a flattened cover crop is an overarching challenge which is consistent with the low level of NT experience observed in Europe [20].

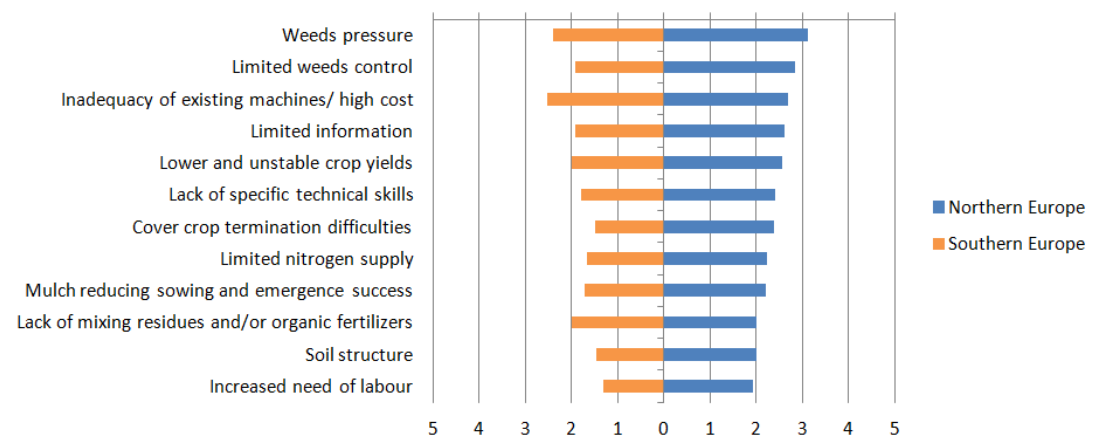

Figure 2. The challenges of no-tillage for 159 European organic farmers (according to Casagrande et al. [19]). The means of Likert scale values of the challenges facing organic farmers in Southern Europe (left) and Northern Europe (right) among the forty interviewed farmers practicing NT in Europe in 2012 are shown. The Likert scale is based on five values: (1) not important, (2) low importance, (3) moderate importance, (4) very important, (5) highly important (the number of interviewed farmers is, respectively, 25 and 15 in northern and southern areas).

Additionally, the high cost and the low availability of NT equipment is a limiting factor in the farmers' ability to invest in effective machinery, with the resulting lack of adequate equipment reducing NT success [8]. Indeed, Peigné et al. [18] have demonstrated the importance of specific machines needed for MBNT production (e.g., roller crimper, NT seeder), which remain very scarce on European organic farms with only a few interviewed farmers rolling the cover crop for termination. Equipment must be designed, manufactured, and/or modified to be more adapted to MBNT [15]. European researchers in conventional farming also presented the small quantity of NT equipment manufactured in Europe as a main challenge [8,46]. Above all, according to Derpsch et al. [46] and Freidrich et al. [56], European farmers who want to use specific and efficient machinery in CA must import the equipment from North America. The authors further explain that while efficient equipment exists in Europe, the lack of technical support for farmers could explain some of the failures observed in NT on European farms. Thus, supporting farmers to build and/or modify NT equipment, or invest in the purchase of NT equipment with other farmers, could generate more appropriate machines to specific soil and climate conditions and reduce costs.

\subsection{Unstable Crop Yields}

Lower yields in NT compared with traditional tillage illustrates the effect of weeds and cover crop competition for water and nutrient resources, which may lead to a lower net return, as evidenced by French farmers [53]. Furthermore, inconsistent crop yields may be exacerbated by climate change, which may be even more profound using NT practices [8]. Under humid and cool conditions, cash crop yields experience greater instability if the cover crop is not successfully managed, leading to insufficient weed control and competition from the cover crop. In southern parts of Europe, the occurrence of summer drought in relation to cash crop planting and establishment may lead to significant yield losses if irrigation is not available, as illustrated by Delate et al. [21] in Iowa. As such, farmers who do implement NT in southern regions tend to use, more frequently, the technique only on winter crops without a cover crop to limit competition with the main crop.

\subsection{Cover Crop Termination}

MBNT and LBNT are challenging for farmers with respect to issues that arise with cover crop termination without the use of synthetic pesticides, relying instead on mechanical methods 
or termination of the cover crop at frost $[18,19]$. Although farmers tend to use frost-sensitive cover crop species (e.g., certain clover species, common vetch (Vicia sativa), etc.), a winter-killed cover crop may not allow for adequate maintenance of residue on the soil surface after the winter and through the cash crop growing season, which is essential to ensure weed suppression until crop harvest, with biomass limited by either fall growth of the cover crop or decomposition of residues. Cover crop termination remains an even greater concern for northern farmers, as wet and cool spring conditions can create an environment fostering strong cover crop growth while soil conditions limit field operations, creating difficulties with management (Figure 2). Additionally, the French survey also indicated additional issues with cover crop management, including the high cost of seed purchasing, greater labor needs, and difficulties related to cover crop establishment (unevenly spread, lack of $\mathrm{N}$ availability) [53].

\subsection{Crop Emergence}

In the case of MBNT, technical and mechanical issues related to direct seeding into a flattened cover crop may limit the seed-to-soil contact and contribute to farmers' concerns regarding crop emergence (Figure 2). This is of particular concern for northern farmers, who must grapple with the challenge of planting through thick cover crop biomass [15]. Moreover, Morris et al. [60] and Soane et al. [8] have highlighted that, in conventional farming systems, soil temperatures are lower under large amounts of residue on the soil surface, delaying crop emergence. Additionally, concerns exist related to limited $\mathrm{N}$ supply to the subsequent cash crops, with slower mineralization rates resulting from cooler soil temperatures and significant soil carbon additions. The challenge regarding $\mathrm{N}$ availability, also noted by Cooper et al. [44], is of even greater importance for northern farmers experiencing lower spring temperatures, thus aggravating the delay in $\mathrm{N}$ supply.

\subsection{Soil Structure}

Improving soil properties is often a primary motivator for farmers interested in adopting CA $[8,19,61]$. Maintaining soil structure, however, may represent a challenge in NT due to the heavy required equipment (e.g., direct seeder, roller crimper) [19]. In particular, topsoil compaction may begin as quickly as five years after the implementation of NT practices in conventional agriculture and seems strongly dependent on soil type and climate $[6,8,62]$. Unstable soil with low organic matter content and greater soil moisture may increase soil compaction, possibly leading to the greater emphasis on soil structure issues cited by northern organic farmers [8]. In Finland, Alakukku et al. [63], cited in Soane et al. [8], observed similar yields in NT soil as a ploughing treatment on silty clay, where lower yields were obtained in NT on clay soil under similar conditions. Soane et al. [8] highlighted that soil compaction is also associated with the previous crop harvest and the lack of tillage prior to sowing subsequent crops. Consequently, the short timeframe between cash crop harvest and cover or cash crop planting in NT does not allow for improved soil structural formation through biological activity.

\subsection{Increased Labor Requirements}

Potential savings in labor is a primary farmer motivation when deciding to adopt NT as documented by European researchers, as significant labor is required for soil tillage [2,53,64]. However, farmers' concerns about increased labor requirements related to the implementation of a cover crop phase may explain why relatively few famers combine NT and cover crops, as perceptions exist that the time required for cover crop management will negatively impact the expected labor-saving benefits of NT.

\section{Overview of Living or Killed (Mulch) Cover Crop-Based No-Tillage Organic Research in Europe}

A recent meta-analysis on shallow non-inversion tillage in OF showed that impacts of NT management on farming system characteristics are poorly documented in Europe [44]. While a significant body of North American research is concentrated on organic NT, European studies are 
focused on RT and are mainly carried out in Germany, France, Switzerland, Greece, Italy, Slovakia, and the Netherlands $[13,47,54,59,65,66]$. Therefore, relatively little knowledge has been provided on organic MBNT or LBNT, despite the recognition by international researchers that this innovation may help to manage weeds and decrease soil disturbance while maintaining biodiversity $[10,17]$. The meta-analysis presented by Cooper et al. [44] indicates that while promising prospects exist related to the improvement of soil quality, substantial yield losses due to perennial weed pressure and the delay in $\mathrm{N}$ supply remain concerns, as evidenced by European organic farmers' challenges outlined in the preceding sections [19].

In Europe, trials including organic NT have been established in Greece, Switzerland, and France (Table 2). These studies have been carried out on NT without the integration of cover crops $[50,67]$, or on CCNT $[15,68,69]$ (Figure 1). In this latter case, most trials have concentrated on using a living cover crop with winter wheat, flax (Linum usitatissimum L.), or quinoa (Chenopodium quinoa L.) crops $[52,68,69]$. Only two studies have been conducted on MBNT in France, in 2005 (corn crop) and 2008 (soybean crop) [15]. Mäder and Berner [13] highlighted that additional NT trials have been led in Europe, such as in Germany, but little feedback on scientific knowledge is easily available within the scientific community because of the different national languages in which these trials were reported.

\subsection{Living Cover Crop-Based No-Tillage (LBNT) Production}

LBNT assessed in Europe is often compared to other tillage techniques mostly relying on traditional tillage $(20-25 \mathrm{~cm})$ and RT $(5-10 \mathrm{~cm})$ [51]. These studies have documented soil fertility improvement in LBNT with higher macroporosity, more organic matter, and higher soil $\mathrm{N}$ content due to benefits provided by the cover crop (biological activity, soil structure, etc.) [50-52,70]. Researchers have also reported the major challenge of identifying the best cover crop species which ensure weed suppression without affecting cash crop yield and quality. For instance, studies conducted in Switzerland on the direct seeding of wheat into a living cover crop demonstrated competition of the cover crop with the main crop [69]. According to Den Hollander et al. [71], clovers, while providing soil fertility benefits, had limited utility for weed control and high competition with the main crop. However, Hiltbrunner et al. [68,69] observed improved weed control with white clover (Trifolium repens L.) and submediterranean clovers (Trifolium lappaceum L.) as compared to alfalfa (Medicago sativa L.), with increased wheat seeding rates potentially improving yield. Across living cover crops trials, overall, researchers have identified white clover as the legume species providing the best compromise between competing with weeds while limiting the competition for light with the wheat crop [69,71,72]. The use of a living cover crop is still debated regarding its potential competition with cash crops and related cash crop yield losses.

Table 2. Published experimental trials, including organic no-tillage techniques in Europe.

\begin{tabular}{|c|c|c|c|c|c|}
\hline Country & Soil Type & Year & Cash Crop & Cover Crop & References \\
\hline \multirow{3}{*}{ France } & Cambisol (silty) & 2003 & corn & clover (living) & \multirow{3}{*}[15,54,73]{} \\
\hline & Fluvisol (sandy & 2005 & corn & alfalfa (mulch *) & \\
\hline & loam) & 2008 & soybean & rye $($ mulch *) & \\
\hline Greece & $\begin{array}{l}\text { Tagnic Eutric } \\
\text { Cambisol } \\
\text { (clay loam) }\end{array}$ & $\begin{array}{l}2007 \\
2008 \\
2010 \\
2011\end{array}$ & $\begin{array}{l}\text { corn } \\
\text { winter wheat } \\
\text { flax } \\
\text { quinoa }\end{array}$ & $\begin{array}{l}\text { Common vetch (Vicia sativa L.) (living), } \\
\text { fababean (Vicia faba L.) (living) }\end{array}$ & {$[50-52,70]$} \\
\hline Switzerland & $\begin{array}{l}\text { Partial gleyic } \\
\text { Cambisol } \\
\text { Orthic Luvisol }\end{array}$ & $\begin{array}{l}2002 \\
2004 \\
2005\end{array}$ & $\begin{array}{l}\text { winter wheat } \\
\text { winter wheat } \\
\text { winter wheat }\end{array}$ & $\begin{array}{l}\text { birdsfoot trefoil (Lotus corniculatus L.), white clover (Trifolium } \\
\text { repens L.), subclover (Trifolium subterraneum ssp.), } \\
\text { strong-spined medick (Medicago truncatula Gaertner) (living) }\end{array}$ & [67-69] \\
\hline
\end{tabular}




\subsection{Cover Crop Mulch-Based No-Tillage (MBNT) Techniques}

In France, where MBNT was tested (Figure 1), four tillage treatments were compared: (1) traditional ploughing (30 cm depth); (2) shallow ploughing (18 cm depth); (3) RT (12 cm-15 cm depth); and (4) MBNT [15]. For this latter treatment, cash crops were sown into a cover crop terminated with a $1.7 \mathrm{~m}$ wide roller crimper with steel blades welded onto a cylinder. This equipment was built following the design model of Brazilian rollers. In 2005, corn was sown into alfalfa mulch and soybean was planted under rye (Secale cereale L.) mulch in 2008. Results showed significantly more earthworms in MBNT with the cover crop biomass left on the soil surface providing food resources which foster biological activity [54]. This finding has been confirmed by several authors in conventional farming who underscore the role of high biological activity in generating resilient organic systems $[6,58]$. Vian et al. [73] showed higher microbial carbon content, organic carbon activity and $\mathrm{N}$ mineralization in MBNT from a 0 to $30 \mathrm{~cm}$ soil depth. These findings are consistent with conventional studies where more soil $\mathrm{C}$ and $\mathrm{N}$ content are observed after longer-term trials, although additional fertilization is often required during the first three years of NT adoption [8,9].

Yield losses were also observed in the two French trials, with $25 \%$ soybean yield reduction in MBNT treatments in 2008 compared to ploughing, and as much as $75 \%$ corn yield reduction under MBNT in 2005 [15]. Crop failures have been attributed to two main factors: (1) weed infestation and (2) cover crop regrowth competition with main crops.

In 2005, alfalfa mulch was unevenly distributed on the soil surface and did not ensure sufficient weed control. More than 100 weeds $/ \mathrm{m}^{2}$ infested the MBNT plots on average, while only one weed $/ \mathrm{m}^{2}$ was observed after ploughing at the corn emergence stage [15]. In North America, studies also indicate contrasting results in maintaining corn yield due to competition by both weeds and the cover crop [21,74]. Indeed, although the Rodale Institute (Pennsylvania, USA) achieved as much as $10.25 \mathrm{t} / \mathrm{ha}$ corn yield in 2007 with a hairy vetch (Vicia villosa L.) cover crop [24], substantial yield losses have also been reported in Iowa due to drought conditions [21]. While legume cover crops increase $\mathrm{N}$ supply to the subsequent corn crop, legume species are also more difficult to terminate through rolling and experience less effective weed control due to their faster residue degradation rate (low $\mathrm{C}: \mathrm{N}$ rate) and lower biomass production as compared to cereal species. This lack of cover crop biomass on the soil surface throughout corn production season could explain the failure observed in the French trial [15] with alfalfa, as well as the interest of some North American researchers to use cover crop mixtures composed of both legume and cereal species prior to corn MBNT [75]. Cereal species could reduce the amount of $\mathrm{N}$ supplied to corn; however, this hypothesis must be further tested to obtain a better understanding of $\mathrm{N}$ dynamics in MBNT production.

In France in 2008, cereal rye demonstrated a greater ability to suppress weeds on soybean MBNT, but did not provide enough biomass to ensure weed control throughout the season [15]. Weed density was more abundant at the end of the cash crop season due to unusually wet conditions. Cereal rye has been the most researched cover crop in North America prior to soybean MBNT and has led to the most promising results regarding the range of benefits conferred (e.g., allelopathic effect, high biomass, early flowering, flexibility of sowing date, kill by rolling, etc.) $[26,39,42,76]$. Researchers also extolled the benefits of other cereal cover crops (e.g., triticale, barley, etc.) related to their longer persistence on the soil surface (high C:N rate) and greater biomass production than legume species. Above all other factors related to cover crop management, according to Mirsky et al. [38], the cover crop must reach more than $8000 \mathrm{~kg} /$ ha to lead to satisfactory weed control [77]. This biomass level was likely not obtained in the European studies.

In France, despite weed infestation, Peigné et al. [15] reported greater soybean populations in MBNT compared with ploughing. The researchers explained that seed predation by pigeons occurring on the trial affected more plants on the ploughed plots because of the lack of mulch cover, which protected the soybean seed and seedlings in the MBNT plots. In North America, Delate et al. [21] and Lefèbvre et al. [78] also tended to observe higher soybean populations in MBNT in the United States and in Canada due to efficient weed control at the early vegetative stage of soybean. In addition, the 
authors indicated that rotary hoeing on ploughed plots likely decreased soybean stands. Based on the French results, we could expect additional benefits from MBNT to ensure crops and soil protection regarding both the risks of pests and climate (storage, drought periods etc.). Substantial work is still required to obtain good weed suppression until crop harvest and maintain similar yields to those obtained in traditional tillage to fully address farmers' concerns [19].

As underlined by a large number of authors, effective cover crop termination is essential to MBNT success [38]. Nevertheless, French researchers have highlighted the difficulty of killing a cover crop with a roller crimper [15]. Indeed, some plots needed to be rolled more than once and cover crop regrowth occurred throughout the crop season, likely impacting cash crop yield [15]. According to North American researchers comparing various stages of cover crop growth and the related efficacy of termination, cover crops must reach at least the flowering growth stage to be successfully controlled $[24,31,38,40]$. However, the French trial experienced difficulties in delaying the sowing of the cash crop due to climate conditions which led to the cover crop being terminated prior to flowering, contributing to the failure to control the cover crop [15]. In light of these problems, North American researchers have screened different cover crop species and cultivars to allow for earlier cover crop flowering the following spring.

\section{European Research Challenges for the Future}

As evidenced by Freidrich et al. [56] in conventional farming, this review of European organic NT trials indicates that projects often compare MBNT or LBNT with other tillage techniques, an experimental framework that does not focus on optimizing MBNT success. Thus, considerable work should be carried out to compare several management systems under various pedo-climatic conditions to find the best strategies leading to the suppression of weeds until crop harvest, yield improvement, and cover crop control.

This paper also indicates the potential soil fertility benefits which could be provided by the further implementation of organic MBNT in Europe [44,54], although there is still a poor understanding of the longer-term effects of MBNT production on soil quality. Furthermore, despite farmers' recognized interest in MBNT, European research has provided very little knowledge to address their concerns (effects on soil structure, NT viability, skills, etc.), thus inhibiting the adoption of MBNT in organic farming. Two primary factors remain poorly researched in Europe, challenging the ability of farmers to maintain crop yields in organic MBNT production: (1) cover crop management (species, cultivars, termination), and (2) reliable, consistent, and effective weed suppression. The following key agronomical issues should be addressed under temperate conditions to eliminate these knowledge gaps:

- Choice of relevant cover crop species: In Europe, few cover crop species have been assessed for MBNT production, even though the appropriate choice of cover crop is essential for efficient weed control [38]. Further screening of species and cultivars under temperate climate conditions is needed to identify optimal cover crop/cash crop combinations and support the decision-making process of farmers. Other questions must also be addressed: Can cover crop species that have given promising results in North America (e.g., rye and triticale) lead to similar results on soybean MBNT in Europe? Which cover crop(s) lead to the best trade-off between weed suppression, crop yield and cover crop control?

- Increasing cover crop biomass: As indicated by many researchers, adequate cover crop biomass is a key factor to ensure weed control in MBNT; however, doubts have been raised regarding the ability to achieve high levels of cover crop biomass (8000-9000 kg/ha) determined to be optimal by North American researchers in Europe, particularly in southern areas. Thus, the following questions must be addressed: What level of cover crop biomass must be reached to ensure satisfactory weed control? Which management strategies could optimize cover crop biomass and achieve a comparable degree of weed suppression as ploughing or chemical methods? How 
does cover crop biomass impact weed development and crop yield? What are the weed control implications of earlier cover crop sowing?

- Improving cover crop termination: Improving cover crop termination by mechanical methods (e.g., rolling-crimping and mowing) leads to greater success in organic MBNT; however, consistent termination of the cover crop remains challenging using the current practices of European farmers. Cover crop termination remains particularly challenging in Northern Europe, where a humid climate fosters vigorous cover crop development. While considerable efforts must be made to develop appropriate machinery adapted to work with the high biomass remaining on the soil surface, further refinement is needed regarding the optimal cover crop termination practices (number of rollings, date of rolling, etc.), with the aim of improving mulch distribution, prolonging its persistence on the ground until crop harvest, and enhancing the quality of crop sowing (seeds/soil contact). In particular, additional studies are required to quantify the effect of cover crop rolling on the mulch degradation rate until crop harvest under a temperate climate and the effectiveness of the roller crimper on legume species termination.

- Designing crop rotation: Integrating MBNT into organic crop rotations in accordance with organic farmers' challenges (e.g., weed management at rotational scale, maintaining crop yields, etc.) while incorporating both production and economic limitations remains a major issue.

Acknowledgments: We acknowledge Paul Mäder (FiBL), F.Xavier Sans (UB), José Manuel Blanco-Moreno (UB), Daniele Antichi (CiRAA), Paolo Bàrberi (SSSA), Annelies Beeckman (INAGRO, department of organic crop production), Federica Bigongiali (SSSA), Julia Cooper (UNEW, NEFG), Hansueli Dierauer (FiBL), Kate Gascoyne (UNEW, NEFG), Meike Grosse (University of Kassel), Juergen Heß (University of Kassel), Andreas Kranzler (FiBL), Anne Luik (EULS), Elen Peetsmann (EULS), Andreas Surböck (FiBL), and Koen Willekens (ILVO), who carried out the European survey within the frame of TILMAN-ORG (www.tilman-org.net) supported by CORE Organic.

Author Contributions: L. Vincent-Caboud reviewed the literature and wrote the initial draft of the paper with assistance from J. Peigné. L. Vincent-Caboud, J. Peigné, M. Casagrande, and E. M. Silva contributed to revising the manuscript.

Conflicts of Interest: The authors declare no conflict of interest.

\section{References}

1. Altieri, M.A.; Lana, M.A.; Bittencourt, H.V.; Kieling, A.S.; Comin, J.J.; Lovato, P.E. Enhancing crop productivity via weed suppression in organic no-till cropping systems in santa catarina, Brazil. J. Sustain. Agric. 2011, 35, 855-869. [CrossRef]

2. Hobbs, P.R.; Sayre, K.; Gupta, R. The role of conservation agriculture in sustainable agriculture. Philos. Trans. R. Soc. B Biol. Sci. 2008, 363, 543-555. [CrossRef] [PubMed]

3. Kassam, A.; Friedrich, T.; Shaxson, F.; Pretty, J. The spread of conservation agriculture: Justification, sustainability and uptake. Int. J. Agric. Sustain. 2009, 7, 292-320. [CrossRef]

4. Masutti, C. Action publique et expertise dans la conservation des ressources agricoles aux états-unis dans les années 1930. Ruralia 2007, 25, 1-25.

5. Horowitz, J. No-Till Farming is a Growing Practice; DIANE Publishing: Collingdale, PA, USA, 2011; p. 28.

6. Cannell, R.Q.; Hawes, J.D. Trends in tillage practices in relation to sustainable crop production with special reference to temperate climates. Soil Tillage Res. 1994, 30, 245-282. [CrossRef]

7. Gohlke, T.; Ingersoll, T.; Roe, R.D.; Oregon, N.; Pullman, W.N. Soil disturbance in no-till and direct seed planting systems. Nat. Res. Conserv. Serv. Agron. Tech. Note 2000, 39, 1-6.

8. Soane, B.D.; Ball, B.C.; Arvidsson, J.; Basch, G.; Moreno, F.; Roger-Estrade, J. No-till in northern, western and south-western Europe: A review of problems and opportunities for crop production and the environment. Soil Tillage Res. 2012, 118, 66-87. [CrossRef]

9. Teasdale, J.R.; Coffman, C.B.; Mangum, R.W. Potential long-term benefits of no-tillage and organic cropping systems for grain production and soil improvement. Agron. J. 2007, 99, 1297-1305. [CrossRef]

10. Triplett, G.B.; Dick, W.A. No-tillage crop production: A revolution in agriculture! Agron. J. 2008, 100, $153-165$. [CrossRef] 
11. Favarato, L.; Galvão, J.; Souza, J.; Guarçoni, R.; Souza, C.; Cunha, D. Population density and weed infestation in organic no-tillage corn cropping system under different soil covers. Planta Daninha 2014, 32, 739-746. [CrossRef]

12. Carrera, L.M.; Abdul-Baki, A.A.; Teasdale, J.R. Cover crop management and weed suppression in no-tillage sweet corn production. HortScience 2004, 39, 1262-1266.

13. Mäder, P.; Berner, A. Development of reduced tillage systems in organic farming in Europe. Renew. Agric. Food Syst. 2012, 27, 7-11. [CrossRef]

14. Watson, C.A.; Atkinson, D.; Gosling, P.; Jackson, L.R.; Rayns, F.W. Managing soil fertility in organic farming systems. Soil Use Manag. 2002, 18, 239-247. [CrossRef]

15. Peigné, J.; Lefevre, V.; Vian, J.F.; Fleury, P. Conservation agriculture in organic farming: Experiences, challenges and opportunities in europe. In Conservation Agriculture; Farooq, M., Siddique, K.H.M., Eds.; Springer International Publishing: Cham, Switzerland, 2015; pp. 559-578.

16. Shirtliffe, S.J.; Johnson, E.N. Progress towards no-till organic weed control in western Canada. Renew. Agric. Food Syst. 2012, 27, 60-67. [CrossRef]

17. Gadermaier, F.; Berner, A.; Fließbach, A.; Friedel, J.K.; Mäder, P. Impact of reduced tillage on soil organic carbon and nutrient budgets under organic farming. Renew. Agric. Food Syst. 2012, 27, 68-80. [CrossRef]

18. Peigné, J.; Ball, B.C.; Roger-Estrade, J.; David, C. Is conservation tillage suitable for organic farming? A review. Soil Use Manag. 2007, 23, 129-144. [CrossRef]

19. Casagrande, M.; Peigné, J.; Payet, V.; Mäder, P.; Sans, F.X.; Blanco-Moreno, J.M.; Antichi, D.; Bàrberi, P.; Beeckman, A.; Bigongiali, F.; et al. Organic farmers' motivations and challenges for adopting conservation agriculture in Europe. Org. Agr. 2015. [CrossRef]

20. Peigné, J.; Casagrande, M.; Payet, V.; David, C.; Sans, F.X.; Blanco-Moreno, J.M.; Cooper, J.; Gascoyne, K.; Antichi, D.; Bàrberi, P.; et al. How organic farmers practice conservation agriculture in europe. Renew. Agric. Food Syst. 2015, 31, 72-85. [CrossRef]

21. Delate, K.; Cwach, D.; Chase, C. Organic no-tillage system effects on soybean, corn and irrigated tomato production and economic performance in Iowa, USA. Renew. Agric. Food Syst. 2012, 27, 49-59. [CrossRef]

22. Halde, C.; Entz, M.H. Plant species and mulch application rate affected decomposition of cover crop mulches used in organic rotational no-till systems. Can. J. Plant Sci. 2016, 96, 59-71. [CrossRef]

23. Halde, C.; Gulden, R.H.; Entz, M.H. Selecting cover crop mulches for organic rotational no-till systems in Manitoba, Canada. Agron. J. 2014, 106, 1193. [CrossRef]

24. Moyer, J. Organic No-Till Farming: Advancing No-Till Agriculture: Crops, Soil, Equipment; Acres U.S.A.: Austin, TX, USA, 2011; p. 204.

25. Parr, M.; Grossman, J.M.; Reberg-Horton, S.C.; Brintin, C.; Crozier, C. Nitrogen delivery from legume cover crops in no-till organic corn production. Crops Soil Mag. Am. Soc. Agron. 2012. [CrossRef]

26. Silva, E.M. Screening five fall-sown cover crops for use in organic no-till crop production in the upper midwest. Agroecol. Sustain. Food Syst. 2014, 38, 748-763. [CrossRef]

27. Davis, A.S. Cover-crop roller-crimper contributes to weed management in no-till soybean. Weed Sci. 2010, 58, 300-309. [CrossRef]

28. Kornecki, T.S.; Arriaga, F.J.; Price, A.J. Roller type and operating speed effects on rye termination rates, soil moisture, and yield of sweet corn in a no-till system. HortScience 2012, 47, 217-223.

29. Kornecki, T.S.; Price, A.J. Effects of different roller/crimper designs and rolling speed on rye cover crop termination and seed cotton yield in a no-till system. J. Cotton Sci. 2010, 14, 212-220.

30. Mirsky, S.B.; Curran, W.S.; Mortenseny, D.M.; Ryany, M.R.; Shumway, D.L. Timing of cover-crop management effects on weed suppression in no-till planted soybean using a roller-crimper. Weed Sci. 2011, 59, 380-389. [CrossRef]

31. Mischler, R.; Duiker, S.W.; Curran, W.S.; Wilson, D. Hairy vetch management for no-till organic corn production. Agron. J. 2010, 102, 355-362. [CrossRef]

32. Parr, M.; Grossman, J.M.; Reberg-Horton, S.C.; Brinton, C.; Crozier, C. Roller-crimper termination for legume cover crops in north Carolina: Impacts on nutrient availability to a succeeding corn crop. Commun. Soil Sci. Plant Anal. 2014, 45, 1106-1119. [CrossRef] 
33. Vaisman, I.; Entz, M.H.; Flaten, D.N.; Gulden, R.H. Blade roller-green manure interactions on nitrogen dynamics, weeds, and organic wheat. Agron. J. 2011, 103, 879-889. [CrossRef]

34. Bernstein, E.R.; Stoltenberg, D.E.; Posner, J.L.; Hedtcke, J.L. Weed community dynamics and suppression in tilled and no-tillage transitional organic winter rye-soybean systems. Weed Sci. 2014, 62, 125-137. [CrossRef]

35. Carr, P.; Gramig, G.; Liebig, M. Impacts of organic zero tillage systems on crops, weeds, and soil quality. Sustainability 2013, 5, 3172-3201. [CrossRef]

36. Carr, P.M.; Anderson, R.L.; Lawley, Y.E.; Miller, P.R.; Zwinger, S.F. Organic zero-till in the northern US great plains region: Opportunities and obstacles. Renew. Agric. Food Syst. 2012, 27, 12-20. [CrossRef]

37. Luna, J.M.; Mitchell, J.P.; Shrestha, A. Conservation tillage for organic agriculture: Evolution toward hybrid systems in the western USA. Renew. Agric. Food Syst. 2012, 27, 21-30. [CrossRef]

38. Mirsky, S.B.; Ryan, M.R.; Curran, W.S.; Teasdale, J.R.; Maul, J.; Spargo, J.T.; Moyer, J.; Grantham, A.M.; Weber, D.; Way, T.R.; et al. Conservation tillage issues: Cover crop-based organic rotational no-till grain production in the mid-atlantic region, USA. Renew. Agric. Food Syst. 2012, 27, 31-40. [CrossRef]

39. Mirsky, S.B.; Ryan, M.R.; Teasdale, J.R.; Curran, W.S.; Reberg-Horton, C.S.; Spargo, J.T.; Wells, M.S.; Keene, C.L.; Moyer, J.W. Overcoming weed management challenges in cover crop-based organic rotational no-till soybean production in the eastern United States. Weed Technol. 2013, 27, 193-203. [CrossRef]

40. Wells, M.S.; Brinton, C.M.; Reberg-Horton, S.C. Weed suppression and soybean yield in a no-till cover-crop mulched system as influenced by six rye cultivars. Renew. Agric. Food Syst. 2015, 31, 1-12. [CrossRef]

41. Wells, M.S.; Reberg-Horton, S.C.; Mirsky, S.B. Cultural strategies for managing weeds and soil moisture in cover crop based no-till soybean production. Weed Sci. 2014, 62, 501-511. [CrossRef]

42. Bernstein, E.R.; Posner, J.L.; Stoltenberg, D.E.; Hedtcke, J.L. Organically managed no-tillage rye-soybean systems: Agronomic, economic, and environmental assessment. Agron. J. 2011, 103, 1169. [CrossRef]

43. Ryan, M.R.; Curran, W.S.; Grantham, A.M.; Hunsberger, L.K.; Mirsky, S.B.; Mortensen, D.A.; Nord, E.A.; Wilson, D.O. Effects of seeding rate and poultry litter on weed suppression from a rolled cereal rye cover crop. Weed Sci. 2011, 59, 438-444. [CrossRef]

44. Cooper, J.; Baranski, M.; Stewart, G.; Nobel-de Lange, M.; Bàrberi, P.; Fließbach, A.; Peigné, J.; Berner, A.; Brock, C.; Casagrande, M.; et al. Shallow non-inversion tillage in organic farming maintains crop yields and increases soil C stocks: A meta-analysis. Agron. Sustain. Dev. 2016. [CrossRef]

45. Baker, C.J.; Saxton, K.E. No-Tillage Seeding in Conservation Agriculture; CABI: Oxfordshire, UK, 2007 ; p. 340.

46. Derpsch, R.; Friedrich, T.; Kassam, A.; Li, H. Current status of adoption of no-till farming in the world and some of its main benefits. Int. J. Agric. Biol. Eng. 2010, 3, 1-25.

47. Armengot, L.; Berner, A.; Blanco-Moreno, J.M.; Mäder, P.; Sans, F.X. Long-term feasibility of reduced tillage in organic farming. Agron. Sustain. Dev. 2014, 35, 339-346. [CrossRef]

48. Emmerling, C. Reduced and conservation tillage effects on soil ecological properties in an organic farming system. Biol. Agric. Hortic. 2007, 24, 363-377. [CrossRef]

49. Krauss, M.; Berner, A.; Burger, D.; Wiemken, A.; Niggli, U.; Mäder, P. Reduced tillage in temperate organic farming: Implications for crop management and forage production. Soil Use Manag. 2010, 26, 12-20. [CrossRef]

50. Bilalis, D.; Kakabouki, I.; Karkanis, A.; Travlos, I.; Triantafyllidis, V.; Dimitra, H. Seed and saponin production of organic quinoa (Chenopodium quinoa Willd.) for different tillage and fertilization. Not. Bot. Horti Agrobot. Cluj-Napoca 2012, 40, 42.

51. Bilalis, D.; Karkanis, A.; Pantelia, A.; Patsiali, S.; Konstantas, A.; Efthimiadou, A. Weed populations are affected by tillage systems and fertilization practices in organic flax (Linum usitatissimum L.) crop. Aust. J. Crop Sci. 2012, 6, 157.

52. Bilalis, D.; Karkanis, A.; Patsiali, S.; Agriogianni, M.; Konstantas, A.; Triantafyllidis, V. Performance of wheat varieties (Triticum Aestivum L.) under conservation tillage practices in organic agriculture. Not. Bot. Horti Agrobot. Cluj-Napoca 2011, 39, 28.

53. Lefèvre, V.; Capitaine, M.; Peigné, J.; Roger-Estrade, J. Soil Conservation Practices in Organic Farming: Overview of French Farmers' Experiences and Contribution to Future Cropping Systems Design. Available online: http:/ /ifsa.boku.ac.at/cms/fileadmin/Proceeding2012/IFSA2012_WS6.3_Lefevre.pdf (accessed on 11 January 2017). 
54. Peigné, J.; Cannavaciuolo, M.; Gautronneau, Y.; Aveline, A.; Giteau, J.L.; Cluzeau, D. Earthworm populations under different tillage systems in organic farming. Soil Tillage Res. 2009, 104, 207-214. [CrossRef]

55. Pelosi, C.; Bertrand, M.; Roger-Estrade, J. Earthworm community in conventional, organic and direct seeding with living mulch cropping systems. Agron. Sustain. Dev. 2009, 29, 287-295. [CrossRef]

56. Friedrich, T.; Kassam, A.; Corsi, S.; Jat, R.A.; Sahrawat, K.L.; Kassam, A.H. Conservation agriculture in europe. In Conservation Agriculture: Global Prospects and Challenges; CABI: Oxfordshire, UK, 2014; pp. 127-170.

57. Bàrberi, P. Weed management in organic agriculture: Are we addressing the right issues? Weed Res. 2002, 42, 177-193. [CrossRef]

58. Emmerling, C. Response of earthworm communities to different types of soil tillage. Appl. Soil Ecol. 2001, 17, 91-96. [CrossRef]

59. Sans, F.X.; Berner, A.; Armengot, L.; Mäder, P. Tillage effects on weed communities in an organic winter wheat-sunflower-spelt cropping sequence. Weed Res. 2011, 51, 413-421. [CrossRef]

60. Morris, N.L.; Miller, P.C.H.; Orson, J.H.; Froud-Williams, R.J. The adoption of non-inversion tillage systems in the United Kingdom and the agronomic impact on soil, crops and the environment-A review. Soil Tillage Res. 2010, 108, 1-15. [CrossRef]

61. Ball, B.C.; Cheshire, M.V.; Robertson, E.A.G.; Hunter, E.A. Carbohydrate composition in relation to structural stability, compactibility and plasticity of two soils in a long-term experiment. Soil Tillage Res. 1996, 39, 143-160. [CrossRef]

62. Munkholm, L.J.; Schjønning, P.; Rasmussen, K.J.; Tanderup, K. Spatial and temporal effects of direct drilling on soil structure in the seedling environment. Soil Tillage Res. 2003, 71, 163-173. [CrossRef]

63. Alakukku, L.; Uusitalo, R.; Särkelä, A.; Lahti, K.; Valkama, P.; Valpasvuo-Jaatinen, P.; Ventelä, A.-M. Phosphorus Stratification in the Ap Horizon of Ploughed and No-Till Soils and Its Effect on P Forms in Surface Runoff. In Proceedings of the ISTRO 18th Triennial Conference Sustainable Agriculture, Izmir, Turkey, 15-19 June 2009; International Soil Tillage Research Organisation: Izmir, Turkey, 2009.

64. Canali, S.; Diacono, M.; Campanelli, G.; Montemurro, F. Organic no-till with roller crimpers: Agro-ecosystem services and applications in organic mediterranean vegetable productions. Sustain. Agric. Res. 2015, 4, 70. [CrossRef]

65. Berner, A.; Hildermann, I.; Fliesbach, A.; Pfiffner, L.; Niggli, U.; Mader, P. Crop yield and soil fertility response to reduced tillage under organic management. Soil Tillage Res. 2008, 101, 89-96. [CrossRef]

66. Lehocká, Z.; Klimeková, M.; Bieliková, M.; Mendel, L. The effect of different tillage systems under organic management on soil quality indicators. Agron. Res. 2009, 7, 369-373.

67. Hiltbrunner, J.; Liedgens, M.; Stamp, P.; Streit, B. Effects of row spacing and liquid manure on directly drilled winter wheat in organic farming. Eur. J. Agron. 2005, 22, 441-447. [CrossRef]

68. Hiltbrunner, J.; Liedgens, M.; Bloch, L.; Stamp, P.; Streit, B. Legume cover crops as living mulches for winter wheat: Components of biomass and the control of weeds. Eur. J. Agron. 2007, 26, 21-29. [CrossRef]

69. Hiltbrunner, J.; Streit, B.; Liedgens, M. Are seeding densities an opportunity to increase grain yield of winter wheat in a living mulch of white clover? Field Crops Res. 2007, 102, 163-171. [CrossRef]

70. Bilalis, D.J.; Karamanos, A.J. Organic maize growth and mycorrhizal root colonization response to tillage and organic fertilization. J. Sustain. Agric. 2010, 34, 836-849. [CrossRef]

71. Den Hollander, N.G.; Bastiaans, L.; Kropff, M.J. Clover as a cover crop for weed suppression in an intercropping design: I. Characteristics of several clover species. Eur. J. Agrono. 2007, 26, 92-103. [CrossRef]

72. Hollander, N.G.D. Growth characteristics of several clover species and their suitability for weed suppression in a mixed cropping design. Ph.D. Thesis, Wageningen University, Wageningen, The Netherlands, 2012.

73. Vian, J.F.; Peigne, J.; Chaussod, R.; Roger-Estrade, J. Effects of four tillage systems on soil structure and soil microbial biomass in organic farming. Soil Use Manag. 2009, 25, 1-10. [CrossRef]

74. Delate, K.; Cwach, D.; Fiscus, M. Evaluation of an Organic No-Till System for Organic Corn and Soybean Production-Agronomy Farm Trial, 2011; Organic Ag Program Webpage, Iowa State University: Ames, IA, USA, 2012.

75. Parr, M.; Grossman, J.M.; Reberg-Horton, S.C.; Brinton, C.; Crozier, C. Nitrogen delivery from legume cover crops in no-till organic corn production. Agron. J. 2011, 103, 1578. [CrossRef]

76. Mirsky, S.B.; Curran, W.S.; Mortensen, D.A.; Ryan, M.R.; Shumway, D.L. Control of cereal rye with a roller/crimper as influenced by cover crop phenology. Agron. J. 2009, 101, 1589. [CrossRef] 
77. Smith, A.N.; Reberg-Horton, S.C.; Place, G.T.; Meijer, A.D.; Arellano, C.; Mueller, J.P. Rolled rye mulch for weed suppression in organic no-tillage soybeans. Weed Sci. 2011, 59, 224-231. [CrossRef]

78. Lefebvre, M.; Leblanc, M.; Gilbert, P.-A.; Estevez, B.; Grenier, M.; Belzile, L. Semis Direct Sur Paillis De Seigle Roulé En Régie Biologique; Institut De Recherche Et De Développement En Agroenvironnement: Québec, QC, Canada, 2011; p. 36. article distributed under the terms and conditions of the Creative Commons Attribution (CC BY) license (http://creativecommons.org/licenses/by/4.0/). 